\title{
OPTIMALISASI PELAYANAN PUBLIK DALAM PERSPEKTIF NEW PUBLICK SERVICEPADA BADAN PENDAPATAN DAERAH KOTA MAKASSAR
}

\author{
Nani Harlinda Nurdin \\ Fakultas Ilmu Sosial dan Ilmu Politik, Universitas Indonesia Timur Makassar \\ Email:nani.harlinda2uit.ac.id
}

\begin{abstract}
Penelitian ini bertujuan untuk mengetahui pelayanan yang diberikan oleh Badan Pendapatan daerah Kota Makassar dalam melaksanakan pelayanan publik khususnya dalam pemberian perizinan reklame dalam perspekktif New Public Service. Penelitian ini menggunakan pendekatan kualitatif dan pemilihan informan dilakukan dengan menggunakan teknik purposive sampling.Hasil penelitian menunjukkan bahwa Badan Pendapatan Daerah Kota Makassar belum sepenuhnya menjalankan prinsip-prinsip New Public Service utamanya pada prinsip Seeks The Public Interest dan Value Citizenship over Entrepreneurship serta pada prinsip Value People, Not Just Productivity, karena masih terjadi perbedaan antara pelayanan yang diberkan pada perizinan reklame yang berbayar dengan perizinan reklame yang tidak berbayar, sedangkan keduanya mempunyai tujuan untuk kepentingan publik.Sehingga perlu membuat strategi untuk merumuskan sasaran yang hendak dicapai dan cara-cara untuk mencapai sasaran tersebut. Sasaran yang tepat merupakan acuan untuk melakukan pengawasan atas kinerja dan hasil kerja yang secara spesifik dapat diukur, relevan dan jelas pelayanan serta pengurusannya sehingga mampu mewujudkan kepuasan bagi pengguna jasa dalam kaitannya dengan optimalisasi pelayanan perizinan reklame dalam perspektif New Public Service dan hal-hal yang berperan dalam menentukan kualitas pelayanan tersebut.
\end{abstract}

Keyword : Optimalisasi dan Pelayanan Publik

\section{PENDAHULUAN}

Pelayanan publik selalu dikaitkan dengan suatu kegiatan yang dilakukan oleh seseorang atau kelompok orang atau instansi tertentu untuk memberikan bantuan dan kemudahan kepada masyarakat dalam rangka mencapai tujuan tertentu. Saat ini pelayanan publik menjadi semakin penting karena senantiasa berhubungan dengan masyarakat yang memiliki kepentingan dan tujuan yang beraneka ragam.

Oleh karena itu institusi pelayanan publik dapat dilakukan oleh pemerintah maupun non-pemerintah. Jika pemerintah merupakan organisasi birokrasi dalam pelayanan publik, maka organisasi birokrasi pemerintahan merupakan organisasi terdepan yang berhubungan dengan pelayanan publik. Dalam hal institusi pemerintah memberikan pelayanan, maka yang terpenting adalah bagaimana memberikan bantuan dan kemudahan kepada masyarakat dalam rangka memenuhi kebutuhan dan kepentingannya.

Pergeseran paradigma pada pengelolaan pemerintahan dari sentralistik ke desentralistik merupakan titik terang dalam melahirkan format peayanan publik yang sesuai dengan azas, prinsip dan standar sehingga dapat mewujudkan pelayanan publik yang berkualitas.

Masih lemahnya kesadaran pemerintah tentang arti penting managemen dan pelayanan kepada masyarakat menyebabkan posisi pemerintah sebagai public servant yang saat ini menjadi harapan masyarakat belum sepenuhnya terwujud, karena masih lemahnya kesadaran pemerintah tentang arti penting managemen dan pelayanan masyarakat. Oleh karenanya birokrasi publik berkewajiban dan bertanggung jawab untuk 
memberikan layanan baik dan profesional. Pelayanan publik (public services) oleh birokrasi publik adalah merupakan salah satu perwujudan dari fungsi aparatur negara sebagai abdi masyarakat di samping sebagai abdi negara dengan maksud untuk mensejahterakan masyarakat.

Pelayanan publik yang ada harus berfungsi untuk mengurangi (bahkan menghilangkan) kesenjangan peran antara organisasi pusat dengan organisasiorganisasi pelaksana yang ada dilapangan. Jumlah staf/aparat yang ada sesuai, tidak kurang dan tidak pada level menengan dan level atas agar pelayanan publik dapat tepat sasaran . pelayanan yang diberikan juga harus mendekatkan birokrasi dengan masyarakat sebagai pelanggan.

Rendahnya kualitas pelayanan publik yang terjadi karena beberapa faktor: pertama ; konteks monopolistik, dalam hal ini karena tidak adanya kompetisi dari penyelenggara pelayanan publik non pemerintah, tidak ada dorongan yang kuat untuk meningkatkan jumlah, kualitas maupun pemerataan pelayanan tersebut oleh pemerintah; kedua:tekanan dari lingkungan, dimana faktor lingkungan amat mempengaruhi kinerja organisasi pelayanan dalam transaksi dan interaksinya antara lingkungan dengan organisasi publik ; ketiga :budaya patrimonial, dimana budaya organisasi penyelenggara pelayanan publik di Indonesia masih banyak terikat oleh tradisi-tradisi politik dan budaya masyarakat setempat yang seringkali tidak kondusif dan melanggar peraturanperaturan yang telah ditentukan.

Salah satu penyelenggaraan pemerintahan daerah adalah pelayanan pemerintahan daerah atau pelayanan publik. Dengan pemberian pelayanan yang baik kepada masyarakat maka pemerintah akan dapat mewujudkan tujuan Negara yaitu menciptakan kesejahteraan masyarakat (Nurcholis, 2007)
Pelayanan publik atau pelayanan umum dapat didefinisikan sebagai segala bentuk jasa pelayanan, baik dalam bentuk barang publik maupun jasa publik yang pada prinsipnya menjadi tanggungjawab dan dilaksanakan oleh instansi Pemerintah di Pusat, di daerah dan lngkungan Badan Usaha Milik Negara/Daerah, dalam rangka upaya pemenuhan kebutuhan masyarakat maupun dalam rangka pelaksanaan ketentuan peraturan perundang-undangan. (Ratminto, 2005)

Lijan Poltak Sinambela menjelaskan tentang arti pelayanan publik. Pelayanan publik adalah pemberian layanan (melayani) keperluan orang atau masyarakat yang mempunyai kepentingan pada organisasi itu sesuai dengan aturan pokok dan tata cara yang telah di tetapkan. (Sinambela, 2006) (Ratminto, 2005)

Dengan demikian pelayan publik adalah pemenuhan keinginan dan kebutuhan masyarakat oleh penyelenggara Negara. Menurut Lijan Poltak Sinambela dengan perkembangan ilmu pengetahuan dan tenologi yang semakin maju dan kompetisi global yang sangat ketat, organisasi yang abisa merebut konsumen potensial hanyalah organisasi yang mampu memberikan pelayanan berkualitas.

Demikian pula lembaga pemerintah semakin dituntut untuk menciptakan kualitas pelayanan yang dapat mendorong dan meningkatkan kegiatan ekonomi. Oleh karena itu, pelayanan aparatur harus lebih proaktif dalam mencermati paradigma baru global agar pelayanannya mempunyai daya saing yang tinggi dalam berbagai aktivitas publik. Untuk itu birokrasi seharusnya menjadi center of excellence, pusat keunggulan pemerintahan.

Wasisto Raharjo Jati menyatakan bahwa pergeseran paradigma penyelenggaraan pelayanan publik menuju pola pelayanan yang lebih transparan, akuntabel dan partisipatif ternyata pada tataran 
implementasi menemui banyak kendala. Kendala tersebut tidak hanya berasal dari sisi aparat pemerintah namun juga dari sisi masyarakat yang belum sepenuhnya percaya terhadap upaya perbaikan yang tengah dilakukan pemerintah.(Jati, 2011)

Dalam melaksanakan pembangunan di setiap daerah, Pemerintah Pusat terlibat sangat dominan dalam proses pengambilan keputusan. Hal ini terjadi karena pembiayaan pembangunan itu sendiri sebagian besar dibiayai langsung oleh pemerintah pusat sedangkan pemerintahan daerah hanya bertindak sebagai pelaksana pembangunan semata sehingga mengakibatkan pelaksanaan pembangunan di daerah terkadang tidak lagi sesuai dengan harapan dan kebutuhan masyarakat setempat. Adanya media baik cetak dan elektronik, dijadikan sebagai modal besar untuk para pengguna sektor perdagangan, salah satu yang paling diminati adalah pemasaran lewat media reklame.

$\begin{array}{ccr}\text { Media } & \text { reklame dianggap } \\ \text { sebagaialternatif } & \text { pemasaran } & \text { yang }\end{array}$
menguntungkan dan sangat efektif, reklame dianggap mampu menarik calon konsumen karena reklame bisa diakses oleh semua pihak.Hal ini menjadikan reklame sebagai salah satu yang harus diperhatikan oleh pemerintah, baik dalam hal pemberian izin, aturan dan tarif pemasangan reklame yang diatur oleh undang-undang maupun peraturan daerah

Melihat potensi pajak reklame yang sedemikian besarnya, maka Pemerintah Kota Makassar diharapkan mampu dan berupaya terus untuk menjaring seluruh potensi Pajak Reklame tersebut untuk menjadikan sebagai bagian dari sumber Pendapatan Asli Daerah.Target realisasi pajak reklame Makassar hingga memasuki triwulan ke-III tahun 2018 cukup memuaskan dengan progres capaiannya sudah mencapai 63 persen atau sekitar Rp22 miliar dari target Rp35 miliar di tahun anggaran 2018. Capaian realisasi pajak tersebut mengalami peningkatan Rp. 4 miliar jika dibandingkan dengan tahun lalu di bulan yang sama, yakni hingga Agustus 2018.

Adapun yang tidak termasuk sebagai objek Pajak Reklame menurut Peraturan Daerah Kota Makassar Nomor 3 Tahun 2010 Tentang Pajak Daerah Bab VI Bagian Kesatu Pasal 26 ayat (4), antara lain adalah reklame yang diselenggarakan oleh pemerintah atau pemerintah daerah, organisasi kemasyarakatan, partai politik, lembaga sosial, keagamaan dan pendidikan tanpa menggunakan label/merk produk dagang.Disinilah prinsip pelayanan dalam perspektif New Public Service dapat dilihat apakah berjalan sebagaimana yang diharapkan?mengingat ada pengurusan reklame yang tidak berbayar, artinya tidak menambah pendapatan.

Salah satu persoalan pada pelayanan publik yang pada Badan Pendapatan Daerah Kota Makassar adalah adanya perbedaan dari segi waktu antara pengurusan reklamae yang berbayar dengan yang tidak berbayar (seperti baliho terkait organisasi sosial) sehingga muncul kesan bahwa pelayanannya agak ribet.Hal ini menyebabkan kurangnya kepercayaan masyarakat terhadap penyelenggaraan pelayanan publik. Yang mana pada hakekatnya manusia membutuhkan pelayanan dan konsep pelayanan akan selalu berada pada kehidupan setiap manusia.

Paradigma baru dalam administrasi publik yang berkaitan dengan pelayanan publik adalah New Public Service (NPS) oleh J.V. Deenhart dan R.B. Denhart.Prinsip utama NPS bahwa peran utama dari administrasi publik adalah memfasilitasi warga untuk mengartikulasikan dan memenuhi kepentingan mereka daripada mencoba untuk mengendalikan atau mengarahkan mereka.(Ulum, 2018) 
Perspektif NPS muncul karenadidukung oleh beberapa tulisan lain yang berkembang beberapa tahun sebelumnya sebagai reaksi terhadap dominasi perspektif new public managemen diberbagai belahan dunia. Pertama, Wansley dan Wolf (1996) melakukan kritik atas reinventing government melalaui "refounding democratic public administration".Mereka mengkompilasi berbagai artikel yang menarasikan betapa perlunya melibatkan masyarakat dalam administrasi publik yang diposisikan sebagai warga negara, bukan sebagai pelanggan semata.Isinya menekankan tentang betapa pentingnya democratic government yang mempromosikan partisipasi masyarakat dalam administrasi publik. Tulisan lainnya dari King dan Stivers (1998) dengan judul "Government is Us: Public Administration in on Anti-government Era".Gagasan yang diusung adalah seyogyanya administrasi publik memandang masyarakat sebagai warga negara (citizen), bukan sekedar pelanggan karena pemerintahan itu memang milik masyarakat.

Akar dari NPS dapat ditelusuri dari berbagai ide tentang demokrasi yang pernah dikemukakan oleh Dimock, Dahl dan Waldo. NPS berakar dari beberapa teori, yang meliputi: 1)Teori democratic citizenship, perlunya pelibatan warganegara dalam pengambilan kebijakan dan pentingnya deliberasi untuk membangun solidaritas dan komitmen guna menghindari konflik; 2)Model komunitas dan civil society, akomodatif terhadap peran masyarakat sipil dengan membangun social trust, kohesi sosial dan jaringan sosial dalam tata pemerintahan yang demokratis; 3) Teori organisasi humanism,administrasi negara harus fokus pada organisasi yang menghargai nilai-nilai kemanusiaan (human beings) dan respon terhadap nilai-nilai kemanusiaan, keadilan dan isu-isu sosial lainnya.; 3) Teori postmodern administrasi publik, mengutamakan dialog (dirkursus) terhadap teori dalam memecahkan persoalan publik daripada menggunakan one best way perspective.

Berasarkan teori yang mendasari munculnya NPS, nampak bahwa NPS mencoba mengartikulasikan berbagi teori dalam menganalisis persoalan-persoalan publik, sehingga menurut Denhardt dan Denhardt paradigma NPS memiliki perbedaan karakteristik dengan NPM.

Tabel 1

Diferensiasi NPM dan NPS

\begin{tabular}{|c|c|c|}
\hline Aspek & $\begin{array}{c}\text { New Public } \\
\text { Managementt }\end{array}$ & $\begin{array}{l}\text { New Public } \\
\text { Services }\end{array}$ \\
\hline $\begin{array}{ll}\text { Dasar } & \text { teoritis } \\
\text { dan } & \text { fondasi } \\
\text { epistimologis }\end{array}$ & Teori Ekonomi & $\begin{array}{l}\text { Teori } \\
\text { Demokrasi }\end{array}$ \\
\hline $\begin{array}{l}\text { Rasionalitas } \\
\text { dan model } \\
\text { perilaku } \\
\text { manusia }\end{array}$ & $\begin{array}{l}\text { Teknis dan } \\
\text { rasionalitas } \\
\text { ekonomi } \\
\text { (economic } \\
\text { man) }\end{array}$ & $\begin{array}{l}\text { Rasionalitas } \\
\text { strategis } \\
\text { atau } \\
\text { rasionaitas } \\
\text { formal } \\
\text { (politik, } \\
\text { ekonomi } \\
\text { dan } \\
\text { organisasi) } \\
\end{array}$ \\
\hline $\begin{array}{l}\text { Konsep } \\
\text { kepentingan } \\
\text { publik }\end{array}$ & $\begin{array}{l}\text { Kepentingan } \\
\text { publik } \\
\text { mewakili } \\
\text { agregasi } \\
\text { kepentingan } \\
\text { individu }\end{array}$ & $\begin{array}{l}\text { Kepentinga } \\
\mathrm{n} \text { publik } \\
\text { adalah hasil } \\
\text { dialog } \\
\text { berbagai } \\
\text { nilai }\end{array}$ \\
\hline $\begin{array}{l}\text { Responsivitas } \\
\text { birokrasi } \\
\text { publik }\end{array}$ & Customer & Citizen's \\
\hline $\begin{array}{l}\text { Peran } \\
\text { pemerintah }\end{array}$ & Steering & Serving \\
\hline $\begin{array}{l}\text { Pencapaian } \\
\text { tujuan }\end{array}$ & $\begin{array}{l}\text { Organisasi } \\
\text { privat dan } \\
\text { nonprofit }\end{array}$ & $\begin{array}{l}\text { Koalisi } \\
\text { antarorgani } \\
\text { sasi publik, } \\
\text { nonprofit } \\
\text { dan privat }\end{array}$ \\
\hline Akuntabilitas & $\begin{array}{l}\text { Bekerja sesuai } \\
\text { dengan } \\
\text { kehendak } \\
\text { pasar } \\
\text { (keinginan } \\
\text { pelanggan) }\end{array}$ & $\begin{array}{l}\text { Multiaspek: } \\
\text { akuntabilita } \\
\text { s } \\
\text { hukum, } \\
\text { nilai-nilai, } \\
\text { komunitas, } \\
\text { norma } \\
\text { politik, } \\
\text { standar } \\
\text { profesional }\end{array}$ \\
\hline
\end{tabular}




\begin{tabular}{|c|c|c|}
\hline $\begin{array}{l}\text { Diskresi } \\
\text { administrasi }\end{array}$ & $\begin{array}{l}\text { Diskresi } \\
\text { diberikan } \\
\text { secara luas }\end{array}$ & $\begin{array}{l}\text { Diskresi } \\
\text { dibutuhkan } \\
\text { tetapi } \\
\text { dibatasi dan } \\
\text { bertanggun } \\
\text { g-jawab }\end{array}$ \\
\hline $\begin{array}{l}\text { Struktur } \\
\text { organisasi }\end{array}$ & $\begin{array}{l}\text { Desentralisasi } \\
\text { organisasi } \\
\text { dengan kontrol } \\
\text { utama berada } \\
\text { pada para agen }\end{array}$ & $\begin{array}{l}\text { Struktur } \\
\text { kolaboratif } \\
\text { dengan } \\
\text { kepemilikan } \\
\text { yang } \\
\text { berbagi } \\
\text { secara } \\
\text { internal dan } \\
\text { eksternal }\end{array}$ \\
\hline $\begin{array}{l}\text { Asumsi } \\
\text { terhadap } \\
\text { motivasi } \\
\text { pegawai } \\
\text { dan } \\
\text { administrator }\end{array}$ & $\begin{array}{l}\text { Semangat } \\
\text { entrepreneur }\end{array}$ & $\begin{array}{l}\text { Pelayanan } \\
\text { publik } \\
\text { dengan } \\
\text { keinginan } \\
\text { melayani } \\
\text { masyarakat }\end{array}$ \\
\hline
\end{tabular}

Sumber: Denhardt dan Denhardt (2003: 2829)

Untuk itulah dalam meningkatkan suatu pelayanan publik yang demokratis, maka pilihan terhadap "the New Public Service (NPS)" dapat menjanjikan suatu perubahan realitas dan kondisi birokrasi pemerintahan.Aplikasi dari konsep ini agak menantang dan membutuhkan keberanian bagi aparatur pemerintahan dalam penyelenggaraan pelayanan publik, karena mengorbankan waktu, tenaga untuk mempengaruhi semua sistem yang berlaku.Alternatif yang ditawarkan adalah pemerintah harus mendengar suara publik dalam berpartisipasi bagi pengelolaan tata pemerintahan.Memang tidak gampang meninggalkan kebiasaan memerintah atau mengatur pada konsep administrasi lama, dari pada mengarahkan, menghargai pendapat sebagaimana yang disarankan konsep NPS.

\section{Prinsip-prinsip The New Public Service}

1. Melayani Warga Negara, bukan customer (Serve Citizens, Not Customers)

New Public Service memandang publik sebagai 'citizen' atau warga negara yang mempunyai hak dan kewajiban publik yang sama. Tidak hanya sebagai customer yang dilihat dari kemampuannya membeli atau membayar produk atau jasa.Citizen adalah penerima dan pengguna pelayanan publik yang disediakan pemerintah dan sekaligus juga subyek dari berbagai kewajiban publik seperti mematuhi peraturan perundangundangan, membayar pajak, membela Negara, dan sebagainya. New Public Service melihat publik sebagai warga negara yang mempunyai hak dan kewajiban dalam komunitas yang lebih luas.Adanya unsur paksaan dalam mematuhi kewajiban publik menjadikan relasi Negara dan publik tidak bersifat sukarela. Karena itu, abdi negara tidak hanya responsif terhadap 'customer', tapi juga fokus pada pemenuhan hak-hak publik serta upaya membangun hubungan kepercayaan (trust) dan kolaborasi dengan warga negara.

\section{Mengutamakan Kepentingan Publik (Seeks the Public Interest)}

New Public Service berpandangan aparatur Negara bukan aktor utama dalam merumuskan apa yang menjadi kepentingan publik. Administrator publik adalah aktor penting dalam sistem kepemerintahan yang lebih luas yang terdiri dari warga Negara (citizen), kelompok, wakil rakyat, dan lembaga-lembaga lainnya. Administrator negara mempunyai peran membantu warga negara mengartikulasikan kepentingan publik. Warga negara diberi suatu pilihan di setiap tahapan proses kepemerintahan, bukan hanya dilibatkan pada saat pemilihan umum. Administrator publik berkewajiban memfasilitasi forum bagi terjadinya dialog publik. Argumen ini berpengaruh terhadap peran dan tanggungjawab administrasi publik yang tidak hanya berorientasi pada pencapaian tujuan-tujuan ekonomis tapi juga nilai-nilai yang menjadi manifestasi kepentingan publik seperti kejujuran ,keadilan, kemanusiaan, dan sebagainya. 
3. Kewarganegaraan lebih berharga daripada Kewirausahaan (Value Citizenship over Entrepreneurship)

New Public Service memandang keterlibatan citizen dalam proses administrasi dan pemerintahan lebih penting ketimbang pemerintahan yang digerakkan oleh semangat wirausaha. New Public Service berargumen kepentingan publik akan lebih baik bila dirumuskan dan dikembangkan oleh aparatur Negara bersama-sama dengan warga negara yang punya komitmen untuk memberi sumbangan berarti pada kehidupan bersama daripada oleh manajer berjiwa wirausaha yang bertindak seolah uang dan kekayaan publik itu milik mereka.

Prinsip ini berimplikasi pada peran pemerintah dan relasinya dengan masyarakat. Peran pemerintah di masa lalu lebih bersifat mengarahkan masyarakat melalui fungsi-fungsi yang bersifat langsung dan pengendalian seperti fungsi pengaturan atau regulasi, pemberian layanan, menetapkan aturan dan insentif. Kehidupan masyarakat modern yang makin kompleks menuntut peran pemerintah bergeser dari fungsi controlling ke agenda setting, fasilitasi, negosiasi atau "brokering" solusi untuk memecahkan problemproblem publik (seringkali dengan melibatkan koalisi badan -badan pemerintah, privat dan nonprofit). Untuk itu, administrator publik tidak cukup hanya menguasai keahlian kontrol manajemen tapi juga keahlian bernegosiasi dan resolusi konflik.

4. Berpikir Strategis, Bertindak Demokratis (Think Strategically, Act Democratically)

Ide utama prinsip ini adalah bahwa kebijakan dan program untuk menjawab kebutuhan publik akan dapat efektif dan responsif apabila dikelola melalui usaha kolektif dan proses kolaboratif. Prinsip ini berkaitan dengan bagaimana administrasi publik menerjemahkan atau mengimplementasikan kebijakan publik sebagai manifestasi dari kepentingan publik.

Fokus utama implementasi dalam New Public Service pada keterlibatan citizen dan pembangunan komunitas (community building). Keterlibatan citizen dilihat sebagai bagian yang harus ada dalam implementasi kebijakan dalam sistem demokrasi. Keterlibatan disini mencakup keseluruhan tahapan perumusan dan proses implementasi kebijakan. Melalui proses ini, warga Negara merasa terlibat dalam proses kepemerintahan bukan hanya menuntut pemerintah untuk memuaskan kepentingannya. Organisasi menjadi ruang publik dimana manusia (citizen dan administrator) dengan perspektif yang berbeda bertindak bersama demi kebaikan publik.Interaksi dan keterlibatan dengan warga Negara ini yang memberi tujuan dan makna pada pelayanan publik.

5. Tahu kalau Akuntabilitas Bukan Hal Sederhana (Recognize that accountability is not Simple).

Aparatur publik harus tidak hanya mengutamakan kepentingan pasar, mereka harus juga mengutamakan ketaatan pada konstitusi,hukum, nilai masyarakat, nilai politik, standard profesional, dan kepentingan warga negara.

Dalam New Public Management, publik dianalogkan dengan pasar yang terdiri dari individu-individu yang disebut customer. Administrasi publik tidak bertanggungjawab, baik secara langsung atau tidak langsung, kepada warga Negara atau ke publik, tapi lebih bertanggungjawab kepada 'customer'nya dengan cara memberikan pelayanan publik yang memuaskan.

Menurut New Public Service, efisiensi, efektivitas dan kepuasan customer penting, 
tapi administrasi publik juga harus mempertanggungjawabkan kinerjanya dari sisi etika, prinsip demokrasi , dan kepentingan publik. Administrator publik bukan wirausaha atas bisnisnya sendiri dimana konsekuensi ataupun kegagalan akibat keputusan yang diambilnya akan ditanggungnya sendiri. Resiko atas kegagalan suatu implementasi kebijakan publik akan ditanggung semua warga masyarakat. Karena itu akuntabilitas administrasi publik bersifat komplek dan multifacet atau banyak dimensi seperti pertanggungjawaban profesional, legal, politis dan demokratis.

6. Melayani Ketimbang Mengarahkan (Serve Rather than Steer)

Kepemimpinan dalam New Public Service terfokus pada energi manusia untuk kemanfaatan kemanusiaan.Kepemimpinan sektor publik berlandaskan pada nilai disebut 'moral atau transformational leadership', bukan 'transactional leadership'.Kepemimpinan transaksional digerakkan atas dasar motif timbal balik atau saling menguntungkan antara pimpinan dan pengikut, atasan dan bawahan. Kepemimpinan moral atau transformasional adalah kepemimpinan yang mampu menjadi aspirasi dan keteladanan moral baik bagi pimpinan, bawahan, maupun publik secara keseluruhan. Kepemimpinan moral menghasilkan tindakan yang konsisten dengan kebutuhan, kepentingan, dan aspirasi pengikut maupun tindakantindakan yang secara fundamental merubah moral dan kondisi sosial.Pada akhirnya kepemimpinan ini mempunyai kapasitas untuk menggerakkan kelompok, organisasi, dan masyarakat menuju pencapaian tujuan yang lebih tinggi.

Kepemimpinan dalam New Public Service merupakan 'shared leadership' dimana kendali kepemimpinan tidak terpusat di tangan atasan tapi melibatkan banyak orang, banyak kelompok. Kedudukan pimpinan disini bukan sebagai pemilik tapi pelayan publik atau abdi masyarakat (servant, not owner).

7. Menghargai Manusia, Bukan Sekedar Produktivitas (Value People, Not Just Productivity)

New Public Service tidak melihat manusia sebagai pemalas atau hanya mementingkan dirinya sendiri.Perilaku manusia juga didorong oleh faktor martabat manusia (human dignity), rasa memiliki dan dimiliki (belongingness), perhatian pada orang lain, pelayanan, dan kepentingan publik.Karena itu ukuran kinerja pegawai tidak semata parameter ekonomi tapi juga nilai-nilai kejujuran, kesetaraan, responsivitas, pemberdayaan, dan sebagainya.Yang perlu disadari dalam kinerja pegawai negeri adalah kita tidak dapat mengharapkan pegawai negeri untuk memperlakukan masyarakat dengan hormat, jika mereka sendiri sebagai manusia tidak diperlakukan oleh pimpinannya sesuai dengan harkat kemanusiaannya.

Perspektif new public service juga memperoleh dukungan intelektual dari karya Box (1998) yang berjudul "citizen governance".Karya ini sekaligus juga menjelaskan bahwa gagasan dari perspektif ini juga telah merambah administrasi publik pada tingkatan pemerintahan daerah. Box menyarankan bahwa pemerintahan daerah seyogyanya direstrukturisasi sehingga mampu meningkatkan keterlibatan masyarakat dalam proses kepemerintahan. Box mengungkapkan bahwa terdapat empat prinsip yang dipergunakan untuk menjelaskan mengapa demokratisasi administrasi publik perlu dilakukan pada tingkatan pemerintahan daerah. Pertama adalah the scale principle yang menjelaskan bahwa terdapat beberapa fungsi yang lebih 
tepat diatur dan diurus pada tingkatan pemerintah pusat dan terdapat beberapa fungsi lain yang lebih tepat diatur dan diurus pada tingkatan pemerintahan daerah. Jika penyelenggaraan suatu fungsi ingin melibatkan partisipasi masyarakat yang lebih besar maka sebaiknya diberikan pada tingkatan pemerintahan daerah karena lebih memungkinkan masyarakat berpartisipasi lebih aktif dan efektif. Kedua adalah the democracy principle yang menjelaskan bahwa pada dasarnya proses pemerintahan seharusnya melibatkan masyarakat. Prinsip menekankan perlunya pembahasan kebijakan dan pengambilan keputusan secara terbuka dan bebas.Partisipasi masyarakat merupakan kunci penyelenggaraan prinsip ini.Ketiga adalah the accountability principle yang menjelaskan bahwa pemerintahan pada dasarnya adalah milik masyarakat.oleh karena itu, akuntabilitas publik berarti pertanggung jawaban kepada masyarakat sebagai pemilik pemerintahan. Untuk mencapai akuntabilitas publik dibutuhkan keterlibatan masyarakat dalam proses kebijakan bersama dengan para wakilnya dan administrator publik. Akuntabilitas publik menuntut adanya keterkaitan langsung warga masyarakat dengan penyusunan dan pelaksanaan programprogram publik. Keempat adalah the rationality principle yang menjelaskan bahwa proses partisipasi publik dalam pemerintahan daerah haruslah ditanggapi secara rasional. Pengertian rasional dalam hal ini lebih mengacu pada kesadaran dan pengakuan bahwa proses partisipasi membutuhkan waktu yang memadai, pemikiran yang cermat, kesempatan kepada masyarakat untuk menyatakan pendapatnya, perlunya mendengar beragam pendapat yang muncul serta penghargaan atas perbedaan pendapat(Alamsyah, 2016)

Berdasarkan seluruh uraian di atas, perspektif new public service membawa angin perubahan dalam administrasi publik. Perubahan ini pada dasarnya menyangkut perubahan dalam cara memandang masyarakat dalam proses pemerintahan, perubahan dalam memandang apa yang dimaksud dengan kepentingan masyarakat, perubahan dalam cara bagaimana kepentingan tersebut diselenggarakan, dan perubahan dalam bagaimana administrator publik menjalankan tugas memenuhi kepentingan publik. Perspektif ini mengedepankan posisi masyarakat sebagai warga negara dalam konteks penyelenggaraan pemerintahan.Perspektif ini membawa upaya demokratisasi administrasi publik.Pelayanan kepada masyarakat merupakan tugas utama bagi administrator publik sekaligus sebagai fasilitator bagi perumusan kepentingan publik dan partisipasi masyarakat dalam pemerintahan.Perspektif ini juga mengakui bahkan menuntut adanya partisipasi masyarakat dalam berbagai jenjang pemerintahan, termasuk daerah.Dalam penyelenggaraan pemerintahan lokal, partisipasi masyarakat merupakan unsur penting dalam perspektif new public service, yang merupakan perspektif baru dalam administrasi publik.

\section{METODE PENELITIAN}

Penelitian ini menggunakan pendekatan kualitatif. Metode penelitian kualitatif adalah metode penelitian yang digunakan untuk meneliti pada kondisi obyek yang alamiah, dimana peneliti adalah sebagai instrumen kunci, teknik pengumpulan data dilakukan secara triangulasi (gabungan), analisis data bersifat induktif, dan hasil penelitian kualitatif lebih menekankan makna dari pada generalisasi.Pemilihan informan dilakukan dengan menggunakan teknik purposive sampling, menjadi sumber informasi utama dalam penelitian ini adalah 1) Kepala Sub Bidang Reklame Badan Pendapatan Daerah 
Kota Makassar; 2) Staf Sub Bidang Reklame

Badan Pendapatan Daerah Kota Makassar, 3) Masyarakat Pengguna Reklame sebanyak 7 Orang.Untuk memperoleh data-data yang Relevan, Akurat, dan dapat dipertanggung jawabkan dalam penelitian ini, digunakan 1) Observasi (Observation), 2) Wawancara (Interview), dan 3) Studi kepustakaan (library research).

\section{HASIL DAN PEMBAHASAN}

Optimalisasi pelayanan perizinan reklame sejalan dengan perspektif dan prinsip-prinsip New Public Service yang dilaksanakan pleh Badan Pendapatan daerah Kota Makassar akan disajikan dan dianalisa dengan enam elemen dimensi berikut ini:

1. Pembatasan Prosedur

Prosedur harus dirancang sependek mungkin sehingga konsep one stop shop benar- benar diterapkan. Penyerahan berkas merupakan salah satu bentuk pelayanan yang dilakukan oleh Badan Pendapatan Daerah Kota Makassar tepatnya Bidang Reklame ketika masyarakat pengguna reklame pertama kali Mengajukan Izin Reklame atau dapat dikatakan merupakan prosedur awal pengurusan Izin Reklame.

Persyaratan dan prosedur yang sederhana sesuai dengan yang telah dijanjikan sebelumnya ini diterapkan agar masyarakat pengguna jasa mendapatkan kemudahan dalam memenuhi syarat syarat yang telah ditetapkan untuk pengajuan izin reklame. Hal ini juga diungkapkan oleh informan lainnya yakni Bapak A.Razak yang datang untuk mengurus Reklame:

"Prosedurnya sederhana dek dan tidak ribet, Cuma memang selanjutnya kita harus antri dan bersabar karena yang mengurus reklame pajak kan tidak hanya kita sendiri.Paling kalau rame antri hampir 1 jam dek. Dimanapun kantornya kan namanya prosedur memang begini. Namanya juga prosedur kan memang harus
dijalankan."(Wawancara,28 Maret 2017).

Sedangkan berikut adalah tanggapan dari Ibu Prisda yang sedang menunggu antrian :

"Untuk masalah pembatasan prosedur saya kurang tau dek.Yang jelas saya selaku pengguna reklame melengkapi persyaratan sesuai prosedur yang diperintahkan. Kalau pengguna reklame memenuhi syarat saat pengurusan reklame (dalam hal ini pembayaran pajak reklame), otomatis pelayanan nya cepat". (Wawancara, 23 Maret 2017).

Dari hasil keterangan yang diperoleh tersebut, dapat diketahui bahwa prosedur pengurusan / pelayanan di Kantor Badan Pendapatan Daerah Kota Makassar sudah diciptakan sesederhana mungkin dan sesuai dengan ketentuan peraturan yang berlaku agar masyarakat yang mengurus reklame dapat dengan mudah menjalankannya serta mendapatkan pelayanan yang baik.

2. Empati dengan customer

Pegawai yang melayani urusan perizinan dari instansi penyelenggara jasa perizinan dapat berempati dengan masyarakat pengguna jasa pelayanan.Empati merupakan rasa peduli untuk memberikan perhatian kepada masyarakat terhadap kebutuhan yang sedang membutuhkan pelayanan.Sebagai instansi publik yang memberikan pelayanan dituntut untuk selalu siap dalam membantu masyarakat yang membutuhkan pelayanan.Kepedulian pegawai untuk selalu mengutamakan kebutuhan masyarakat akan mendukung terciptanya efektitas pelayanan. Empati juga merupakan kekuatan yang meningkatkan ikatan kepercayaan antara semua pihak yang terikat. Bila para pegawai di bidang reklame sudah mampu memahami pertanyaanpertanyaan pengguna reklame, maka mereka secara otomatis akan memiliki intuisi untuk menciptakan pelayanan, ataupun komunikasi yang sesuai dengan kebutuhan para pelanggan. Untuk itu peneliti mewawancarai beberapa pegawai 
diantaranya Bapak Adiyanto Said,ST dan Bapak Ridwan terkait dengan sikap empati atau kepedulian yang ditunjukkan oleh petugas pelayanan kepada masyarakat, yaitu:

"Memperhatikan kebutuhan
masyarakat itu sangat penting ,dengan memperhatikan dan memberikan pelayanan yang terbaik ,kami rasa itu akan membuat masyarakat yang datang mengurus akan merasa nyaman dalam proses mengurus reklame".(Wawancara,14 Maret 2017)

"Sebagai pegawai yang bertanggungjawab kami wajib memberikan pelayanan yang empati terhadap pemohon yang datang mengurus ." (Wawancara,20 Maret 2017)

Dengan adanya pendapat diatas bisa di katakan bahwa empati dengan costumer itu adalah salah satu tanggujawab sebagai pegawai untuk memberikan pelayanan yang empati kepada masyarkat.

Adapun beberapa pendapat masyarakat mengenai adanya empati yang di berikan pegawai saat melakukan pengurusan izin reklame, Oleh Ibu Prisda, Bapak A.Razak, Ibu Samsinar dan Bapak Rahmat yaitu :

"pegawainya sudah menjelaskan sedetail mungkin mengenai reklame dek. Pelayanan pegawainya bisa diterima dengan baik oleh masyarakat karena pegawai juga menerima kritik maupun saran dengan sepenuh hati sebagai interopeksi untuk pelayanan yang lebih baik". (Wawancara,23 Maret 2017)

"Proses pelayanan pegawai terhadap masyarakat sudah cukup baik karena pemberian pelayanan terhadap masyarakat sudah cukup jelas dek". (Wawancara,28 Maret 2017)

"pasti semua orang menginginkan pelayanan yang bagus dek disertai dengan empati yang bagus pula. Saya sebagai pemohon reklame menginginkan hal tersebut". (Wawancara,21 April 2017)

"Tanggungjawab seorang pegawai itu sangat penting dalam memberikan pelayanan,,saya datang mengurus reklame di kantor ini merasa sangat di perhatikan dengan adanya empati dari pegawai yang sedang dinas". (Wawancara,10 April 2017)

Dalam hal pelayanan, para pegawai yang sukses selalu memiliki empati yang kuat, sehingga mereka bisa dengan cepat bereaksi untuk memberikan pelayanan sesuai kebutuhanpelanggan. Dan juga, empati yang mereka miliki mempertajam keyakinan hati dan menginformasikan realitas dengan benar, sehingga mereka dapat segera mengambil keputusan yang cepat, untuk mempermudah proses pelayanan sesuai keinginan pelanggan.

3. Kejelasan Tata Cara Pelayanan

Tata cara pelayanan harus di desain sesederhana mungkin dan di komunikasikan kepada masyarakat pengguna jasa pelayanan. Adanya kejelasan tata cara pelayanan yang diberikan oleh pegawai terkait dalam memberikan pelayanan, serta menyangkut pelayanan informasi pegawai dalam memberikan pemahaman secara global tentang pelayanan perizinan reklame. Kemampuan pegawai yang profesional sangat penting dalam melaksanakan tugas secara baik. Untuk mengetahui bagaimana kejelasan tata cara pelayanan pegawai dalam memberikan pelayanan kita lihat penuturan oleh Bapak Adiyanto Said,ST dan Bapak Ridwan tentang kejelasan tata cara pelayanan di bawah ini yaitu :

"dengan adanya kejelasan tata cara pelayanan akan membuat pengurusan berkas lebih mudah,baik kepada kami selaku pegawai maupun masyarakat yang datang melakukan pengurusan. Untuk itu kami selalu mengarahkan para pemohon ketika melakukan pengurusan reklame".(Wawancara,14 Maret 2017) 
"Penggunan jasa izin reklame pasti menginginkan tata cara kejelasan pelayanan oleh sebab itu kami selaku pemberi pelayanan berusaha semaksimal mungkin untuk memberikan pelayanan yang terbaik dengan begitu para pengguna reklame akan merasa puas atas pelayanan yang kami berikan". (Wawancara, 20 Maret 2017)

Menurut beberapa pendapat diatas dapat disimpulkan bahwa dengan adanya kejelasan tata cara pelayanan yang baik,yang di berikan oleh pegawai kepada masyarakat akan membuat pengurusan berkas lebih mudah.

Menurut Kotler dalam Sampara Lukman (Lijan Poltak Sinambela , 2006) berpendapat, pelayanan adalah suatu kegiatan atau urutan kegiatan yang terjadi dalam interaksi langsung antarseseorang dengan orang lain atau mesin secara fisik, dan menyediakan kepuasan pelanggan. Adapun beberapa pendapat masyarakat mengenai kejelasan tata cara pelayanan oleh Ibu Samsinar, Bapak Rifky, Ibu Fitri dan Bapak Rahmat yaitu sebagai berikut:

"Ya bagi saya dek Pelayanan yang saya terima disini cukup memuaskan karena sangat jelas tata carapelayanannya".(Wawancara,2 1 April 2017)

"saya mengurus pajak reklame berbayar dek. kalau masalah pelayanannya Alhamdulillah lancar dan baik. saya mengatakan hal demikian itu karena saya sudah bayar pajak jadi mungkin proses pelayanannya agak cepat".'Wawancara, 11 Agustus 2017)

"pelayanan yang saya terima saat saya mengurus di kantor ini bagi saya itu sesuai dengan yang saya harapkan, karena pengurusan yang saya lakukan berjalan dengan lancar dan tidak ribet."(Wawancara, 5 april 2017).

"Berbicara mengenai pelayanan yang saya terima saat melakukan pengurusan ya itu lumayan bagus dek, hanya saja saya juga harus sabar menunggu untuk mendapatkan pelayanan karena di ruangan ini bukan hanya saya yang ingin dilayani."(Wawancara, 10 April 2017)

Melihat dari beberapa pendapat pengguna reklame diatas, bisa dikatakan bahwa mereka sudah merasa puas atas pelayanan yang diterima dari pihak kantor. Akan tetapi berbeda halnya dengan salah satu pengguna reklame yang mengurus reklame tidak berbayar, Bapak Arif yang berpendapat mengenai pelayanan yang diterima yaitu sebagai berikut:

"menurut saya kalau kejelasannya ya begitu jelas-jelas saja tapi saya lihat pelayanannya kurang maksimal, karena pelayanannya agak lama, sementara masih banyak orang yang menunggu untuk dilayani pengurusan reklame. Mungkin karena saya mengurus reklame yang tidak berbayar (baliho terkait organisasi sosial) jadi pelayanannya agak ribet".(Wawancara,9 Agustus 2017).

Sesuai dengan beberapa pendapat narasumber diatas, dapat dipastikan bahwa dalam pelayanan itu harus jelas tata cara pelayanannya demi kelancaran pengurusan reklame, karena dengan kejelasan tata cara pelayanan akan lancar sesuai dengan yang di harapkan, meskipun ada beberapa pendapat masyarakat yang menilai bahwa pelayanannya kurang maksimal .

4. Transparansi Biaya

Transparansi biaya mempersyaratkan ketersediaan informasi biaya yang akurat dan cermat.Transparansi juga merujuk pada keterbukaan informasi sehingga orang dapat menggunakannya untuk melacak penyalahgunaan wewenang dan 
memperjuangkan kepentingan mereka. Berikut ini pendapat Bapak Adiyanto Said,ST selaku kepala Sub bidang Reklame dan Bapak Ridwan sebagai staf Sub bidang Reklame yaitu :

"berbicara transparansi biaya itu artinya biaya atau pajak yang harus dibayar oleh pemohon dan hal itu sudah di tetapkan. Seperti halnya reklame insidentil biayanya sudah ditentukan dilihat dari ukuran dan berapa hari pemohon mengajukan izin pemasangan reklamenya. Namun beda halnya dengan reklame permanen yang dilihat dari ukuran dan pajaknya harus dibayar pertahun. Jadi transparansi biaya kepada pemohon itu sudah sangat jelas".(Wawancara, 14 Maret 2017)

"adanya keterbukaan mengenai biaya itu sudah menjadi bagian dari kantor kami supaya tidak terjadi kesalahpahaman antara pegawai dengan masyarkat yang sedang melakukan pengurusan pemasangan reklame". (Wawancara,20 Maret 2017)

Pendapat diatas menunjukkan bahwa transparansi biaya itu sudah jelas dan diperuntukkan pada pemohon/pengguna reklame agar mengetahui daftar pajak/retribusi reklame, sehingga tidak akan menimbulkan kesalahpahaman atau kecurangan antara pegawai dan masyarakat yang melakukan pengurusan reklame.

Sedangkan menurut beberapa pendapat masyarakat (pengguna reklame) yaitu ibu Prisda,Ibu Samsinar,Bapak A.Razak,Bapak Rifky, dan Bapak Arif adalah sebagai berikut :

"ya bagus dong ,karena dengan begitu kan kami sebagai masyarakat yang mengurus bisa tau berapa biaya yang harus dibayar ketika mengajukan permohonan izin reklame, sehingga prosesnya lancar". (Wawancara,23 Maret 2017)

"menurut saya mungkin masalah keterbukaan biaya itu mengenai pajaknya ". (Wawancara,21 April 2017)

"bagi saya pribadi sebagai masyarakat,hal itu sebetulnya bagus karena dengan adanya keterbukaan biaya seperti itu masyarakat pasti tahu dan tidak merasa ragu saat ingin membayar". (Wawancara,28 Maret 2017).

"mengenai transparansi biaya itu sesuai dengan daftar pajak yang ada, contohnya saya yg memohon pemasangan reklame baliho ukuran $3 \times 4$ itu biayanya sudh jelas,dan saya langsung saja membayar pajak yang ditetapkan". (Wawancara,11 Agustus 2017).

"menurut saya kalau masalah biaya pemohon tidak bisa negosiasi lagi karena jelas-jelas sudah ada daftar pajak bagi pemasangan reklame yang permanen ataupun sementara. Seperti saya yang mengurus reklame yang tidak berbayar,ya saya tidak membayar". (Wawancara,9 Agustus 2017)

Dari beberapa pendapat diatas dapat dikatakan bahwa biaya adalah hal yang tak pernah luput dari apapun itu,tanpa biaya sesuatu hal bisa saja tertunda atau tidak terlaksana. Biaya pelayanan harus ditetapkan seminimal mungkin dan setransparan mungkin demi kelancaran pengurusan izin reklame.

\section{KESIMPULAN DAN SARAN Kesimpulan}

Dari keseluruhan pemaparan tersebut dapat ditarik kesmpulan bahwa dalam menjalankan pelayanan publik pada perizinan reklame, Badan Pendapatan Daerah Kota Makassar belum sepenuhnya menjalankan prinsip-prinsip new public service, seperti pada prinsip seeks the public interest dan Value Citizenship over Entrepreneurship serta pada prinsip Value People, Not Just Productivity, karena masih terjadi perbedaan antara pelayanan yang diberkan pada perizinan reklame yang berbayar dengan perizinan reklame yang 
tidak berbayar, sedangkan keduanya mempunyai tujuan untuk kepentingan publik.

\section{Saran}

Untuk itu Kantor Badan Pendapatan Daerah Kota Makassar perlu membuat strategi untuk merumuskan sasaran yang hendak dicapai kantor dan cara-cara untuk mencapai sasaran tersebut. Sasaran yang tepat merupakan acuan untuk melakukan pengawasan atas kinerja dan hasil kerja secara spesifik dapat diukur, relevan dan jelas pelayanan serta pengurusannya sehingga mampu mewujudkan kepuasan bagi pengguna jasa dalam kaitannya dengan optimalisasi pelayanan perizinan reklame dalam perspektif New Public Service dan hal-hal yang berperan dalam menentukan kualitas pelayanan tersebut.

\section{DAFTAR PUSTAKA}

Alamsyah, A. (2016). PERKEMBANGAN PARADIGMA ADMINISTRASI PUBLIK ( New Public Administration, New Public Management dan New Public Service ). 04(2).

Jati, W. R. (2011). Inovasi Pelayanan Publik Setengah Hati : Studi Pelayanan Publik SAMSAT Kota Yogyakarta. Jurnal Ilmu Sosial dan Ilmu Politik, 68.

Nurcholis, H. (2007). Teori dan Praktek Pemerintahan dan Otonomi Daerah. Jakarta: Grasindo.

Ratminto, A. S. (2005). Manajemen Pelayanan: Pengembangan Modal Konseptual Penerapan Citizen's Charter dan Standar Pelayanan. Jogyakarta: Pustaka Pelajar.

Sinambela, L. P. (2006). Reformasi

Pelayanan Publik, Teori, Kebijakan dan Implementasi. Jakarta: PT. Bumi Aksara.

Ulum, M. C. (2018). Public Service Tinjauan Teoritis dan Isu-isu Strategis Pelayanan Publik. Malang: UB Press. 